\title{
Synchronization of Zygote Production in Saccharomyces cerevisiae
}

\author{
By T. BILIŃSKI, J. LITWIŃSKA, J. ŻUK AND W. GAJEWSKI \\ Institute of Biochemistry and Biophysics, Polish Academy of Sciences, \\ Warsaw, 02-532, Poland
}

(Received 25 April 1973; revised 20 June 1973)

SUMMARY

A method of synchronous mass production of yeast zygotes is described. A yield of 30 to $40 \%$ zygotes with the period of formation restricted to $\mathrm{I} h$ was achieved. This result was obtained by determining optimal parameters for different steps of sexual fusion of haploid $a$ and $\alpha$ cells in yeast.

\section{INTRODUCTION}

The mechanism of sexual fusion in yeast is a very complicated process consisting of many steps. Yanagishima (1971) has shown that there are hormonal steps preparing the fusion of mating types $a$ and $\alpha$ and formation of diploid zygotes. Recently Duntze, MacKay \& Manney (I970) have demonstrated that the cells of $\alpha$ mating type excrete a diffusible peptide substance, $\alpha$ factor, which inhibits division in $a$ cells. This factor specifically inhibits the initiation of DNA synthesis in $a$ cells (Throm \& Duntze, I970; Bücking-Throm, Duntze, Hartwell \& Manney, I973). The $\alpha$ factor is produced constitutively by $\alpha$ cells and it may induce $a$ cells to produce a diffusible factor which influences the $\alpha$ cells, preparing them for conjugation. To be competent for sexual fusion the cells of both mating types must be in an appropriate stage. They must not be budding, and DNA synthesis must be stopped so that the nuclei of both conjugating types are at the same stage (Hartwell, I973).

A population of synchronously formed young zygotes is essential for any kind of future biochemical or genetical analysis of processes occurring in zygotes. The aim of the work described in the present paper was to determine the optimal physiological conditions for formation of yeast zygotes.

In $1962 \mathrm{Jacob}$ described a method for synchronized formation of yeast zygotes. However, the synchronization was rather poor, as the yield of zygotes, although much higher than in Lindegren's classic method, was still low (only up to about I $5 \%$ ) and the time from the appearance of the first zygotes to the maximum of their frequency was about three hours.

When studying the formation of diploid cells on selective media the results are much influenced by the presence of clumps formed as a result of sexual agglutination (Sakai \& Yanagishima, I97I) and the yield obtained is overestimated owing to new zygote formation in these clumps.

The main advantage of Jacob's method was to enforce contact between competent haploid cells by centrifugation. This resulted in an almost hundredfold rise in the yield of zygotes. To raise the yield and to obtain a truly synchronous population of zygotes we have modified Jacob's basic procedure. 


\section{METHODS}

Strains. The following strains were used: M/82-I $\alpha$ leu $_{1}$ ade $_{1}, \mathrm{M} / 82-2 a \mathrm{leu}_{1} \mathrm{thr}_{2-1}$; originating from cross 55R5/3c a ura $\times \mathrm{S}_{2} 6 \mathrm{I}_{5 \mathrm{~B}} \propto \mathrm{thr}_{2-1} \mathrm{tyr}_{4} \mathrm{leu}_{1}$ ade $_{1}$ ade $_{5}$. The strain 55R5 was obtained from Professor Slonimski (Gif-sur-Yvette) and strain S26I5B from Professor Mortimer (Donner Laboratory, University of California, Berkeley).

Media. The basal medium YE $3 \%$ for zygote formation was that used by Jacob (1962), and consisted of $3 \%$ glucose and $\mathrm{I} \%$ yeast extract. The lowering of glucose content or its removal lowered or prevented zygote formation. For yeast culture the YPG medium was used, consisting of I \% yeast extract, I \% Difco-Bacto-Peptone and $2 \%$ glucose.

Estimation of zygote yield by selective plating. The number of zygotes was estimated by plating on minimal medium (Galzy \& Slonimski, 1957) containing $2 \%$ glucose and supplemented with leucine on which, in this cross, only diploids can grow. The total number of cells was estimated from simultaneous plating on YPG medium. The cells were sonicated before plating. The number of haploid $a$ and $\alpha$ cells during conjugation was established by plating on minimal medium supplemented with leucine, leucine plus adenine, and leucine plus threonine and methionine, respectively.

Estimation of zygote yield by counting in a haemacytometer. The samples of cultures or of incubation mixtures were cooled in an ice bath, sonicated and immediately counted with a haemacytometer. Budded haploid cells were counted as two units, and single cells and budded or unbudded zygotes as one unit. At least 500 cells were scored for each determination.

Culture. Both haploid strains were cultivated in $350 \mathrm{ml}$ Erlenmeyer flasks containing I00 $\mathrm{ml}$ of YPG medium for $\mathrm{I} 8 \mathrm{~h}$ at $30^{\circ} \mathrm{C}$ on an orbital shaker (I $\left.20 \mathrm{rev} . / \mathrm{min}\right)$. The concentration of cells in inocula was $3 \times 10^{5}$ for $a$ strain and $2 \times 10^{6}$ for $\alpha$ strain.

Harvesting. The cells were collected at the beginning of stationary phase by centrifugation for $5 \mathrm{~min}$ at $3000 \mathrm{~g}$ (Sorvall SS-I) in $50 \mathrm{ml}$ steel tubes, sterilized with $70 \%$ ethanol.

\section{RESULTS AND DISCUSSION}

Sexual agglutination results in the formation of clumps which sediment, and also in a lower optical density of the suspension of conjugating haploid cells. The changes in optical density thus reflect the processes of sexual agglutination. Fig. I shows the dependence of changes in optical density of suspensions of $a$ and $\alpha$ haploid cells on the $\mathrm{pH}$ of the incubation medium. The optimal $\mathrm{pH}$ for sexual agglutination of haploid cells was about 6 . Beyond the $\mathrm{pH}$ range 5 to 7 the agglutination reaction dropped rapidly.

When the rate of zygote formation in samples of incubation medium was directly measured in the same conditions as for agglutination we obtained a very similar curve of dependence of zygote formation on the $\mathrm{pH}$ values of the incubation medium (Fig. 2) with the optimum at $\mathrm{pH} 6$.

When the conjugating mixture was centrifuged and the conjugation took place in a pellet, the optimal $\mathrm{pH}$ for zygote formation was $4 \cdot 5$. The yield of zygotes after centrifugation was much higher, as one of the limiting factors in zygote formation in a suspension of haploid cells is the low chance of contact among the competent cells, and centifugation increased contacts among cells. In such conditions the optimal $\mathrm{pH}$ was 4.5 which coincided with the optimal $\mathrm{pH}$ for the $\alpha$ factor action as determined by W. Duntze (personal communication).

The optimal density of haploid cells for zygote formation both for cells in suspension 


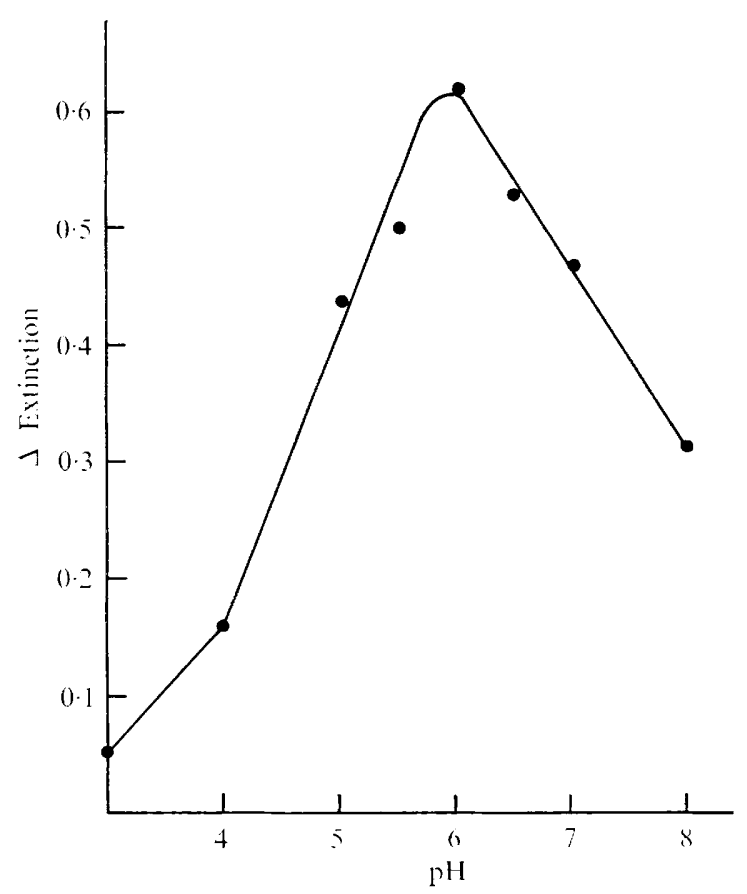

Fig. I. Effect of $\mathrm{pH}$ on cell agglutination in Saccharomyces cerevisiae after $2 \mathrm{~h}$ incubation of $\alpha$ and $a$ strains. The suspensions of $10^{8}$ cells $/ \mathrm{ml}$ of $a$ and $\alpha$ cells in YE $3 \%$ were prepared and adjusted to

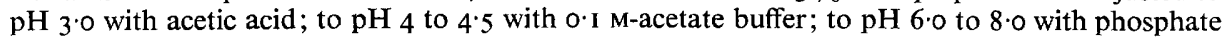
buffer; to above $\mathrm{pH} 8.0$ with $0 . \mathrm{I}$ M-tris- $\mathrm{HCl}$ buffer. Strains were mixed I : I and incubated for $2 \mathrm{~h}$ at $30^{\circ} \mathrm{C}$ in an orbital shaker. The details of culture, harvesting, incubation and conjugation conditions were as in Methods. After $2 \mathrm{~h}$, $10 \mathrm{ml}$ samples of conjugation mixture were poured into $10 \mathrm{ml}$ graduated test-tubes and, after standing for $10 \mathrm{~min}$, a $3 \mathrm{ml}$ sample was taken from the top of the tube, diluted three times, and the absorbance was measured at $700 \mathrm{~nm}$ in $\mathrm{I} \mathrm{cm}$ cuvettes with a Specol spectrocolorimeter. Treated in the same way, the initial suspension had an extinction of $\mathrm{I} \cdot \mathrm{I}$. At the end of the experiment $\mathrm{pH}$ values were checked, and differences were no more than $0 . \mathrm{I} \mathrm{pH}$ unit. The pH was measured with a Radiometer 22.

and after centrifugation was about $10^{6}$ to $10^{7} / \mathrm{ml}$ of incubation medium. When the concentration rose above $10^{8} / \mathrm{ml}$, the yield of zygotes was much lower.

Another important factor for effective zygote formation was an adequate relative proportion of opposite mating types in the mixture. We examined the influence of the concentration of opposite mating-type cells on the yield of zygotes, changing the concentration from $10^{7}$ to $10^{8}$ cells $/ \mathrm{ml}$ and maintaining the concentration of the other mating type at $10^{7}$ cells $/ \mathrm{ml}$. The resulting two curves (Fig. 3 ) show that when $\alpha$ cells were maintained at $10^{7}$ cells $/ \mathrm{ml}$, and we raised the concentration of $a$ cells from $10^{7}$ to $10^{8}$ cells $/ \mathrm{ml}$, the yield of zygotes rose up to a concentration of $5 \times 10^{7}$ cells $/ \mathrm{ml}$ and then a plateau was reached. When the concentration of $a$ cells was kept constant at ${ }^{1} 0^{7}$ cells $/ \mathrm{ml}$ and the concentration of $\alpha$ cells was raised from $10^{7}$ to $10^{8} \mathrm{cells} / \mathrm{ml}$, the yield of zygotes with the stepwise increasing proportions of $\alpha$ cells decreased continuously. The excess of $\alpha$ cells inhibited in some way the formation of the zygotes.

As can be seen from Fig. 2, centrifugation of the conjugation mixture raised the yield of zygotes nearly a hundredfold. We have found that centrifugation was effective only when applied not later than $2 \mathrm{~h}$ after mixing $a$ and $\alpha$ haploid cells. Contacts among cells may have 


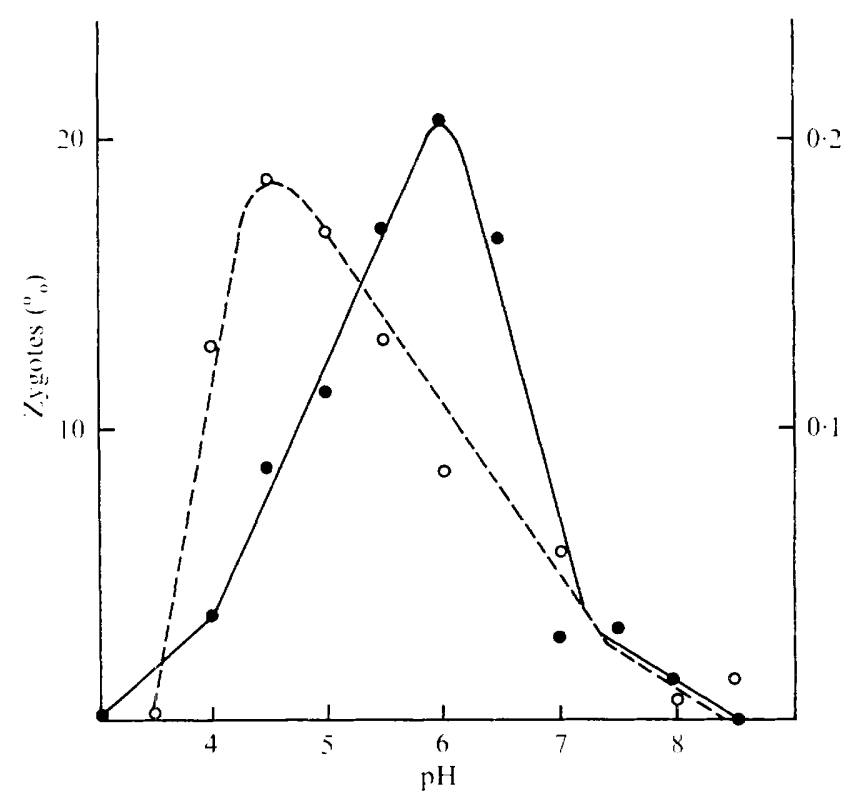

Fig. 2. Effect of pH on cell conjugation in Saccharomyces cerevisiae. out centrifugation; scale on the right. The culture and harvesting conditions and the mugation withfor Fig. I. The suspensions of $2 \times 10^{6} \mathrm{cells} / \mathrm{ml}$ of $a$ and $\alpha$ strains were prepared in media with different $\mathrm{pH}$ values and mixed together in a $\mathrm{I}: \mathrm{I}$ ratio. Ten $\mathrm{ml}$ portions of the mixture in $50 \mathrm{ml}$ tubes were incubated on an orbital shaker at $30^{\circ} \mathrm{C}$ for $2 \mathrm{~h}$ and without shaking at the same temperature for the next $2 \mathrm{~h}$. After that time the samples were sonicated and plated on selective media to determine zygote formation frequency. $\mathrm{O}-----\mathrm{O}$, Conjugation with centrifugation: scale on the left. The preparation of cell suspensions and $2 \mathrm{~h}$ incubation were as for Fig. I. Afterwards $\mathrm{I} \mathrm{ml}$ of suspension was diluted ten times with the medium of the same $\mathrm{pH}$ value and centrifuged for $2 \mathrm{~min}$ at $3000 \mathrm{~g}$ in $10 \mathrm{ml}$ tubes in a Sorvall SSI. After $30 \mathrm{~min}$ the tubes were gently shaken and then incubated at $30^{\circ} \mathrm{C}$ without shaking. Four and a half hours after the initial mixing of both strains the samples were cooled on ice, sonicated and counted under a microscope.

been unnecessary for the early stage because of the ability of hormones to diffuse. Then, when cells were at a suitable stage for conjugation, effective contact between competent cells was necessary. Usually the first conjugation figures appeared $3 \mathrm{~h}$ after the mixing of both mating types and the maximum zygote formation was reached in the following 2 to $3 \mathrm{~h}$.

The effect of $\mathrm{pH}$ during the first $2 \mathrm{~h}$ is shown in Fig. 4. There is a bimodal curve with two optima at $\mathrm{pH} 4.5$ and 8.5 and a minimum at $\mathrm{pH} 6$. In the conditions described in the legend to Fig. 4 , the absolute number of cells after $5 \cdot 5 \mathrm{~h}$ incubation was highest at $\mathrm{pH} 6 \cdot 0\left(\mathrm{I} \cdot 6 \times 10^{7}\right.$ cells $/ \mathrm{ml}$ ). At lower and higher $\mathrm{pH}$ values the number of cells decreased and at $\mathrm{pH} 8.5$ it was nearly the same as at the beginning of incubation $\left(\mathrm{I} \cdot 2 \times 10^{7}\right.$ cells $\mathrm{ml}$ as compared with $1 \mathrm{O}^{7}$ cells $/ \mathrm{ml})$. At the same time the absolute number of zygotes was highest at $\mathrm{pH} 4.5\left(3.4 \times 10^{6}\right.$ zygotes $/ \mathrm{ml})$ and dropped at $\mathrm{pH} 6.0\left(2 \times 10^{6}\right.$ zygotes $\left./ \mathrm{ml}\right)$ and in more alkaline conditions remained practically constant. Thus there is a real optimum for zygote formation at $\mathrm{pH} 4.5$ and this bimodal curve may be the result of an interplay of many processes such as hormonal induction, conjugation, growth and divisions of haploid cells.

To obtain not only a high yield of zygotes but also a high degree of synchrony, it is necessary to restrict the period of their formation to a defined short period of time. At an early stage sexual agglutination occurs and clumps are formed. In clumps zygotes could 


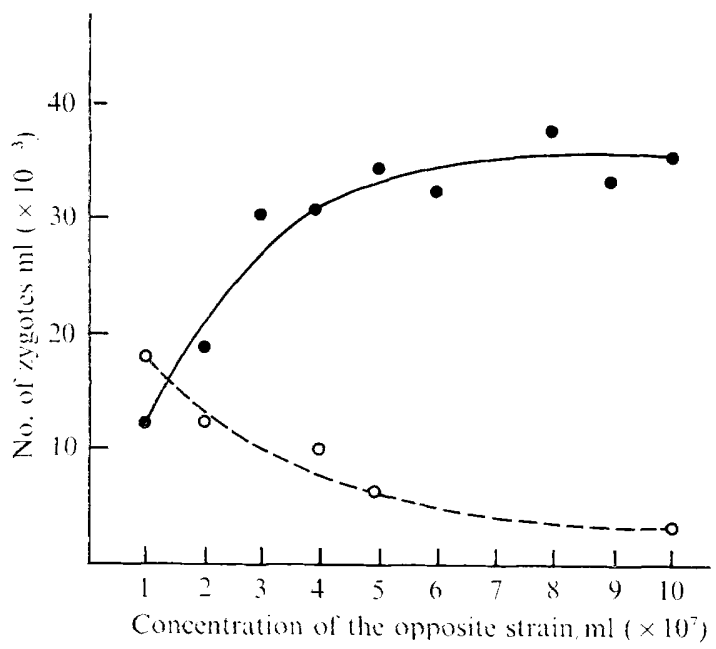

Fig. 3. Yield of zygotes after $4.5 \mathrm{~h}$ incubation of a mixture with different proportions of $a$ and $\alpha$ strains of Saccharomyces cerevisiae. The culture and harvesting conditions were as for Fig. I. Two series of mixtures of both strains in YE $3 \%$ medium $(\mathrm{Jacob}, 1962)$ were prepared: $0---0$, with a constant level of $\alpha$ cells $\left(10^{7}\right.$ cells $\left./ \mathrm{ml}\right)$ and varying concentrations of $a$ cells ranging from $\mathrm{IO}^{7}$ to $1 \mathrm{O}^{8}$ cells $/ \mathrm{ml}$; - , with a constant level of $a$-cells $\left(10^{7}\right.$ cells $\left./ \mathrm{ml}\right)$ and varying concentrations of $\alpha$ cells ranging from $10^{7}$ to $\mathrm{IO}^{8}$ cells $/ \mathrm{ml}$. The two mixtures were incubated for $2 \mathrm{~h}$ on an orbital shaker and without shaking at $30^{\circ} \mathrm{C}$ for a further $25 \mathrm{~min}$. Afterwards the cells were cooled on ice, sonicated and plated on selective media to determine zygote formation frequency. Similar results were obtained with centrifugation.

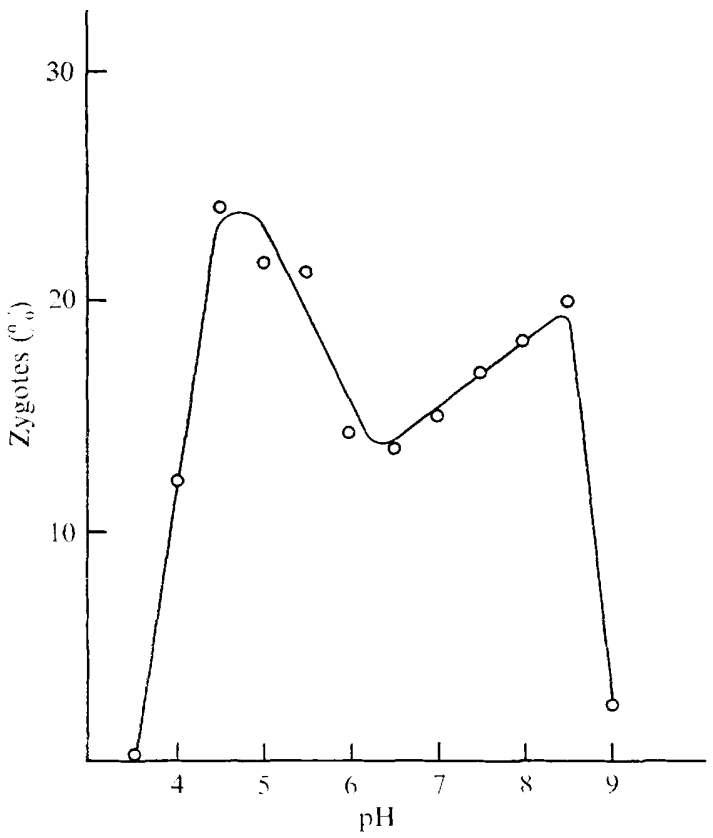

Fig. 4. Effect of $\mathrm{pH}$ on preliminary steps of conjugation in Saccharomyces cerevisiae. The procedure was as for Fig. I. After $2 \mathrm{~h}$ incubation in a given pH the cells were centrifuged and suspended again

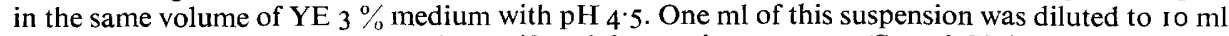
with fresh medium at $\mathrm{pH}_{4.5}$ and centrifuged for $2 \mathrm{~min}$ at $3000 \mathrm{~g}$ (Sorval SSI) in $10 \mathrm{ml}$ tubes. After 30 min the pellet was re-suspended and incubated at $30^{\circ} \mathrm{C}$. Four and a half hours after the initial mixing of parental strains the cells were cooled on ice, sonicated and counted under a microscope. 


\section{Table I. Effect of sonication on zygote formation after various periods of incubation of $a$ and $\alpha$ cells of Saccharomyces cerevisiae}

The culture and harvesting conditions were as in Methods; the conjugation medium was after Jacob (1962). A mixture of $\alpha$ cells ( $10^{7}$ cells $\left./ \mathrm{ml}\right)$ and $a$ cells $\left(5 \times 10^{7}\right.$ cells $\left./ \mathrm{ml}\right)$ was prepared; $100 \mathrm{ml}$ were incubated for $2 \mathrm{~h}$ in $250 \mathrm{ml}$ flasks at $30^{\circ} \mathrm{C}$ on an orbital shaker and further incubated without shaking at $30^{\circ} \mathrm{C}$. Samples ( $10 \mathrm{ml}$ ) were taken each hour and centrifuged for $5 \mathrm{~min}$ at $3000 \mathrm{rev} . / \mathrm{min}$ and suspended in $10 \mathrm{ml}$ water. Samples $(5 \mathrm{ml})$ were sonicated twice for $30 \mathrm{~s}$ (amplitude $2 \mu \mathrm{m}$ from peak to peak with MSE 100 Watt Ultrasonic Disintegrator). The remaining $5 \mathrm{ml}$ portions were not sonicated, and acted as controls. The samples were diluted and plated on selective media.

Time of incubation (h)

0

No. zygotes $/ \mathrm{ml}$ Control
Sonication

$\begin{array}{rrrrrrr}35 & 15 & 2605 & 19800 & 43275 & 91000 & 252000 \\ I & 3 & 14 & 3415 & 34500 & 74000 & 166500\end{array}$

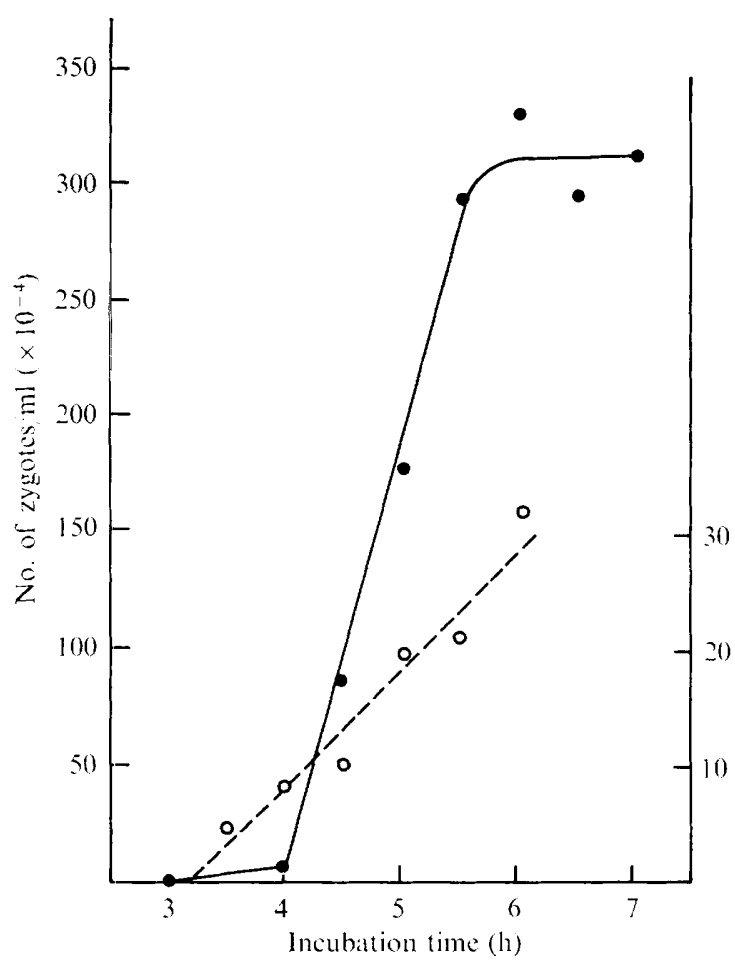

Fig. 5. Formation of zygotes in the conjugation mixture. $\bigcirc---\bigcirc$, Prepared according to the procedure of Jacob (1962), cell concentration $10^{6} / \mathrm{ml}$ for each strain, scale on the right.

Prepared according to the procedure of the authors, cell concentration $5 \times 10^{6} / \mathrm{ml}$, scale on the left. Estimation of the number of zygotes in both cases was by counting under the microscope in the haemacytometer.

arise immediately, but when after $2 \mathrm{~h}$ the suspension is sonicated, the clumps are disintegrated and thus formation of zygotes is prevented. The results of experiments on the influence of sonication on zygote formation are presented in Table I. Sonication during the first $2 \mathrm{~h}$ almost completely prevented the formation of zygotes. The number of zygotes was tested by plating on selective media. When clumps were not disintegrated, then even after plating new zygotes were formed and new diploid colonies appeared on selective medium. 
When the sonication was applied after $4 \mathrm{~h}$ incubation, the yield of zygotes was similar to that in unsonicated control samples. This indicates that sonication did not damage alreadyformed zygotes.

To obtain a high yield of synchronously formed zygotes the following procedure was finally applied. The haploid $a$ and $\alpha$ cells were grown and harvested as indicated in Methods. Suspensions of $\mathrm{I}^{8}$ cells $/ \mathrm{ml}$ in conjugation medium YE $3 \%$ (yeast extract $\mathrm{I} \%$, glucose $3 \%$, at $\mathrm{pH}_{4} .5$ adjusted with $\mathrm{I}$ M-acetic acid) were prepared. The suspensions of both matingtype cells in a I : I ratio were mixed and incubated for $\mathrm{I} \mathrm{h}$ at $30^{\circ} \mathrm{C}$, in $50 \mathrm{ml}$ steel Sorvall centrifuge tubes containing $35 \mathrm{ml}$ of the mixture. Then the cells were centrifuged for $5 \mathrm{~min}$ at $3000 \mathrm{~g}$ (Sorvall $\mathrm{SSI}$ ) and resuspended in $35 \mathrm{ml}$ of $\mathrm{YE} 3 \%$ at $\mathrm{pH} 8.5$ (adjusted with I $\mathrm{M}-\mathrm{Na}_{2} \mathrm{HPO}_{4}$ ). After $\mathrm{I} \mathrm{h}$ incubation the cells were centrifuged in the same conditions, resuspended in $35 \mathrm{ml}$ of fresh $\mathrm{YE} 3 \%$ at $\mathrm{pH}_{4} .5$ and sonicated twice for $30 \mathrm{~s}$ (amplitude $2 \mu \mathrm{m}$ from peak to peak with an MSE Ioo Watt Ultrasonic Disintegrator).

To $250 \mathrm{ml}$ steel centrifuge bottles containing I $80 \mathrm{ml}$ of fresh YE medium, $\mathrm{pH} \mathrm{4.5,20} \mathrm{ml}$ of sonicated suspension were added and immediately centrifuged on a MSE High Speed 18 with an angle rotor $(6 \times 250 \mathrm{ml})$ at room temperature for $2 \mathrm{~min}$ at $3000 \mathrm{rev}$. $/ \mathrm{min}$. The bottles were then incubated at $30^{\circ} \mathrm{C}$ for $30 \mathrm{~min}$ and then gently shaken to suspend the pellet. After another $30 \mathrm{~min}$ incubation they were again shaken to disintegrate the pellet and the suspension re-incubated without shaking.

With this procedure the first zygotes did not appear until $4.5 \mathrm{~h}$ incubation. During the next hour the number of zygotes rose abruptly, and then showed no further increase (Fig. 5). In Fig. 5 the kinetics of zygote formation by our procedure and that of Jacob (I962) are compared. We see not only that the yield of zygotes is much higher, but also that the synchronization of their formation is much improved, as practically all zygotes are formed during $\mathrm{I} h$. After $5.5 \mathrm{~h}$ incubation the maximum percentage of zygotes in the whole yeast population is also reached. After that time the increase of diploid cell number is already the result of the separation of buds from the zygotes and their subsequent divisions.

Using this procedure we were able to increase the yield of zygotes to about 30 to $40 \%$. This percentage is calculated from the number of cells after $5.5 \mathrm{~h}$ conjugation during which some haploid cells have divided. About 60 to $70 \%$ of the initial number of haploid cells are involved in conjugation. The high degree of synchrony results from preventing zygote formation during the first $2 \mathrm{~h}$ by creating conditions unfavourable for cell fusion, such as suboptimal $\mathrm{pH}$, high cell concentration, and sonication. Then conditions are optimized for cell fusion and the cells are forced into contact. This yield could be raised further by disintegrating the pellet and afterwards centrifuging the cells several times, but then synchronization would be lost. It is quite possible that this yield of zygotes is nearly the highest possible by such a technique, since in a pellet of immobilized cells the spatial relations do not permit more effective pairing between competent cells. This assumption is supported by the fact that $95 \%$ of $\alpha$ cells are competent. Using the conjugation technique described above we have found that only $5 \%$ of $\alpha$ cells were still haploid when the $a$ cells were more than four times as numerous in the initial mixture.

This work was supported by the Polish Academy of Sciences under Project 0.9.3. I. 


\section{REFERENCES}

Bücking-Throm, E., Duntze, W., Hartwell, H. \& Manney, T. R. (I973). Reversible arrest of haploid yeast cells at the initiation of DNA synthesis by a diffusible sex factor. Experimental Cell Research 76, 99-110.

Duntze, W., Mackay, V. \& Manney, T. R. (1970). Saccharomyces cerevisiae: A diffusible sex factor. Science, New York 168, I $472-\mathrm{I} 473$.

Galzy, P. \& Slonimski, P. P. (1957). Variations physiologiques de la levure au cours de la croissance sur l'acide lactique ou sur glucose comme seule source de carbone. Comptes rendus des séances de l'Académie des sciences $245,2423$.

HARTWELl, L. H. (I973). Synchronization of haploid yeast cell cycles, a prelude to conjugation. Experimental Cell Research 76, I I I-I I 7.

$\mathrm{J}_{\mathrm{ACOB}}$, H. (1962). Technique de synchronisation de la formation des zygotes chez la levure Saccharomyces cerevisiae. Comptes rendus des séances de l'Académie des sciences 254, 3909-39I I.

SaKaI, K. \& YanaGishima, N. (I97I). Mating reaction in Saccharomyces cerevisiae. I. Cell agglutination related to mating. Archiv für Mikrobiologie 75, 260-265.

Throm, E. \& Duntze, W. (1970). Mating-type dependent inhibition of deoxyribonucleic acid synthesis in Saccharomyces cerevisiae. Journal of Bacteriology 104, 1388-1390.

Yanagishima, N. (197I). Induced production of sexual hormone in yeast. Physiologia plantarum 24, $260-263$. 